\title{
The expression of surface antigens on three trophoblastic tissues in the mouse
}

\author{
Jan Carter \\ Department of Biochemistry, Trinity College, Dublin 2, Ireland
}

\begin{abstract}
Summary. The expression of paternal and maternal antigens on three types of mouse trophoblast cultured in vitro has been examined with the mixed haemadsorption test. Primary trophoblastic giant cells outgrown from blastocysts and placental trophoblast from 16-day pregnancies expressed antigens of both sources at all stages in culture. Secondary trophoblastic giant cells outgrown from the tip of 8-day ectoplacental cones did not give a positive reaction until they had outgrown for 3-5 days. Microdensitometry after Feulgen staining showed that the cells which gave a positive mixed haemadsorption response were polyploid. Incubation of blastocysts and ectoplacental cone tissue with progesterone, oestradiol-17 $\beta$ and hCG did not affect the results.
\end{abstract}

\section{Introduction}

The cells of the trophoblast are generally accepted as being involved in the proposed fetal-maternal barrier which permits maternal acceptance of the fetus (Edwards \& Coombs, 1974). Their role is not fully understood; it has been suggested that there is some non-cellular barrier associated with the trophoblast layers (Kirby, Billington, Bradbury \& Goldstein, 1964; Currie \& Bagshawe, 1967) which renders them antigenically inert. Experiments using neuraminidase-treated ectoplacental cone trophoblast (Currie, Van Doorninck \& Bagshawe, 1968) supported this view, but Simmons, Lipschultz, Rios \& Ray (1971) were unable to repeat these results. Ectoplacental cone grafts are not rejected unless the host is presensitized (Simmons \& Russell, 1967) and do not presensitize hosts to allogeneic skin grafts (Searle, Jenkinson \& Johnson, 1975). Hulka \& Mohr (1968), however, demonstrated that ectoplacental cone could immunize the host. Whole placenta can induce hypersensitivity to paternal strain alloantigens and placental tissue grafts have been shown to be susceptible to rejection (Uhr \& Anderson, 1962; Schlesinger, 1964).

The confusing nature of the evidence for the antigenicity of trophoblast may be due in part to the difficulties of separating trophoblast from other tissue elements. In the mouse it is possible to isolate trophoblast from 3 different stages of development and to grow it in vitro: the stages are (1) primary giant cells outgrown from the blastocyst, (2) secondary giant cells from the ectoplacental cone, and (3) placental trophoblast. Paternal and maternal antigens have been demonstrated on the primary trophoblastic giant cells of the mouse by the mixed haemadsorption technique (Carter, 1976b; Sellens, 1977). Billington, Jenkinson, Searle \& Sellens (1977) showed that H-2 and non-H-2 antigens were expressed on 5-day outgrowths of ectoplacental cone and placental trophoblast of 12-15-day-pregnant mice.

In the present study, paternal and maternal antigens on the three types of mouse trophoblast, cultured in vitro, were examined by the mixed haemadsorption technique

\section{Materials and Methods}

The inbred mice used were of the C57/BL10/ScSn $\left(\mathrm{H}-2^{b}\right)$ and CBA/Fa(H-2 $\left.{ }^{\mathrm{k}}\right)$ strains and are subsequently referred to as C57 or CBA animals. Ovulation was spontaneous or induced at 4 weeks of age by intraperitoneal injections of 5 i.u. PMSG (Folligon: Intervet, Cambs) followed by 5 i.u. hCG (Chorulon: Intervet, Cambs) $48 \mathrm{~h}$ later, i.e. $12 \mathrm{~h}$ before the middle $\mathrm{f}_{\mathrm{B}}$ the $_{\text {subsequent }}$ dark $_{4}$ period 
(Gates, 1971). Females were caged with males during this dark period and checked for vaginal plugs the following morning. The day of finding a vaginal plug was designated Day 1.

\section{Trophoblast tissue}

Primary giant cell trophoblast from blastocysts was obtained on Day 4 by flushing uteri of superovulating females with phosphate-buffered saline (PBS). Acid-washed sterile coverslips were placed in sterile tissue-culture dishes and the blastocysts were cultured in small drops of Snow's medium (Ansell \& Snow, 1975) supplemented with 10\% fetal calf serum (FCS: Gibco Bio-Cult, Glasgow) under light liquid paraffin. The blastocysts were incubated at $37^{\circ} \mathrm{C}$ in an atmosphere of $5 \% \mathrm{CO}_{2}$ in air, controlled by a $\mathrm{CO}_{2}$ monitor (Gow-Mac Instruments, Shannon, Ireland). After 2-3 days in culture the blastocyst has usually hatched, attached and begun to outgrow: this stage was designated ' $a o^{\prime}$. Approximately 1 day later outgrowth was complete and the culture was designated ' $o$ '.

Secondary giant cells from ectoplacental cone trophoblast were obtained by dissection of embryos from their deciduas on Day 8 of pregnancy (naturally ovulating females). A small piece of tissue was cut from the tip of each ectoplacental cone and only those pieces which were thought to be small enough to exclude any cells from the ectoplacental core (Johnson, 1975) were cultured in Trowells T-8 medium (Gibco Bio-Cult) supplemented with 10\% FCS. Medium was changed after $48 \mathrm{~h}$. Other culture conditions were identical to those described for blastocyst culture. During the first $24 \mathrm{~h}$, the ectoplacental cone tissue attached and a few layers of secondary giant cells outgrew; this was designated 'ao' (see Pl. 1, Fig. 1). The radius of the outgrowth continued to increase and later stages were designated 'o' (see Pl. 1, Fig. 1).

Placental trophoblast from 16-day-pregnant mice was outgrown in Trowells T-8 medium in the same way, taking approximately $1 \times 1 \mathrm{~mm}$ pieces of spongiotrophoblast. These were cultured for 1 or 4 days.

Hormones used in the culture medium (see 'Results') were progesterone and oestradiol-17 $\beta$ (Sigma, St. Louis, U.S.A.) and hCG (Chorulon; Intervet, Cambs).

\section{Antisera}

An antiserum to a mixture of male and female CBA or C57 spleen cells was raised in C57 or CBA mice respectively. Approximately half a donor spleen in PBS was given by intraperitoneal injection every week for 5-10 weeks. Test bleeds were made to determine the cytotoxicity of the antisera against target lymphocytes.

An antiserum to sheep red blood cells was raised in A-strain mice. Recipients were given $\mathbf{0 . 2} \mathrm{ml}$ of a $1 \%$ suspension of sheep RBCs intraperitoneally each week for 7-10 weeks. The serum was collected and stored at $-20^{\circ} \mathrm{C}$. Rabbit anti-mouse IgG was obtained from Cappell Laboratories, Downington, U.S.A.

\section{Mixed haemadsorption test}

The test used was that of Fagraeus, Espmark \& Jonsson (1965). Optimal conditions for the sensitization of sheep RBCs were established in a chessboard experiment with RBCs sensitized with different concentrations of anti-sheep RBC and anti-mouse Ig serum (Tachibana, Worst \& Klein, 1970). Fresh erythrocytes were washed three times in PBS, incubated in a 1:1000 dilution of mouse anti-sheep RBC serum followed by a 1:100 dilution of rabbit anti-mouse IgG serum and finally diluted to $4 \%(\mathrm{v} / \mathrm{v})$ and stored at $4^{\circ} \mathrm{C}$ in PBS for periods up to 1 week. Incubations were carried out at $37^{\circ} \mathrm{C}$ for $1 \mathrm{~h}$ and there were three washes with PBS between each step in the procedure.

To prepare the outgrowths for the test, oil was removed from the coverslips by rinsing in PBS at $37^{\circ} \mathrm{C}$ and they were then incubated for $1 \mathrm{~h}$ at $37^{\circ} \mathrm{C}$ with a $1: 160$ dilution of anti-CBA serum or a $1: 40$ dilution of anti-C57 serum. The sera were not fractionated or heat-inactivated. After rinsing with PBS the cultures were layered with sensitized sheep RBCs $(1 \%, v / v)$ for a further hour at room temperature. Unattached erythrocytes were washed off with PBS and the amount of attachment was estimated by using phase-contrast microscopy. The positive controls for the antisera were on cultures of epidermis from 16-day fetuses. The blastocysts were scored according to the percentage of target cells (i.e. trophoblast and inner cell mass of the outgrowth) to which the sensitized RBCs were 
attached. The ectoplacental cone and placental outgrowths were scored according to the percentage of target cells of the outermost layer of the outgrowth to which the sensitized RBCs were attached. The score was expressed on the following scale: 4.0 (100\% attachment), $3.5(90 \%), 3.0(50-80 \%)$, $2.0(25-50 \%), 1.0(10-25 \%), 0.5(1-10 \%), 0(0 \%)$ (Carter, 1976b). There was no adherence of sensitized sheep RBCs in the absence of antisera.

\section{Histology}

Permanent mounts of outgrowths on coverslips were made by fixation for $1 \mathrm{~h}$ in Bouin's fluid, followed by staining with haematoxylin and eosin and mounting with neutral glycerine jelly (Difco, West Molesey, Surrey).

\section{Microdensitometry}

Ectoplacental cone tissue was obtained from the outermost layer of cells of 2- or 4-day outgrowths. Imprints of the cut surface of liver were used as control tissue. Nuclear DNA in all cells was demonstrated by the Feulgen reaction with the following schedule: fixation in ethanol : glacial acetic acid $(3: 1 \mathrm{v} / \mathrm{v})$ for $10 \mathrm{~min}$, hydrolysis for $40 \mathrm{~min}$ in $5 \mathrm{~N}-\mathrm{HCl}$ at room temperature, two rinses in distilled water, Schiff's reagent for $2 \mathrm{~h}$, three sulphite rinses of $10 \mathrm{~min}$ each. The coverslips were then washed in running tap water and mounted in glycerine jelly.

A microdensitometer (M-85: Vickers Instruments Ltd, York) was used for measurement of the intensity of Feulgen staining and integrated scans were carried out at $565 \mathrm{~nm}$. All readings were corrected for background absorption. A standard of 70-80 liver nuclei was used for evaluating the basic DNA content of the trophoplast cells. Liver nuclei are diploid, tetraploid or octoploid and contain $2 \mathrm{C}, 4 \mathrm{C}$ or $8 \mathrm{C}$ units of DNA. The haploid amount of DNA is $\mathrm{C}$ and by using the mean DNA value of the $2 \mathrm{C}$ liver nuclei as a standard, the frequency distribution of the trophoblast cells could be plotted on a logarithmic scale.

\section{Ectoplacental cone trophoblast}

\section{Results}

The expression of surface antigens on cells of the ectoplacental cone after 1-5 days of culture is shown in Table 1 . All CBA $\times$ CBA outgrowths incubated with anti-C57 serum and C57 $\times$ C57 outgrowths incubated with anti-CBA serum gave negative scores.

Table 1. Expression of CBA and C57 cell surface antigens on ectoplacental cone outgrowths (no. in parentheses) after mixed haemadsorption (mean score \pm s.e.m.)

\begin{tabular}{|c|c|c|c|c|c|}
\hline \multirow[b]{2}{*}{ Parent mating } & \multirow{2}{*}{$\begin{array}{l}\text { Days in } \\
\text { culture }\end{array}$} & \multicolumn{2}{|c|}{ Anti-CBA serum } & \multicolumn{2}{|c|}{ Anti-C57 serum } \\
\hline & & 'ao' & 'o' & 'ao' & 'o' \\
\hline \multirow[t]{3}{*}{$\mathrm{CBA} \times \mathrm{CBA}$} & 1 & $0(14)$ & $2.5 \pm 0.5(2)$ & NE & $\mathrm{NE}$ \\
\hline & 2 & $0(3)$ & $3 \cdot 11 \pm 0.2(9)$ & NE & $0(6)$ \\
\hline & $3-5$ & $0.17 \pm 0.17$ & $3.65 \pm 0.15(20)$ & $\mathrm{NE}$ & $0(4)$ \\
\hline \multirow[t]{2}{*}{$\mathrm{C} 57 \times \mathrm{C} 57$} & 2 & NE & $0(5)$ & $0(12)$ & NE \\
\hline & 5 & $\mathrm{NE}$ & $0(5)$ & NE & $2.54 \pm 0.18$ \\
\hline
\end{tabular}

$\mathrm{NE}=$ not examined.

All ' $O$ ' outgrowths of CBA $\times$ CBA ectoplacental cones incubated with anti-CBA serum gave scores exceeding 2.5 and all 'ao' outgrowths were negative (P1. 1, Fig. 2) with one exception, a 4-day 'ao' outgrowth which gave a score of 0.5 . The same response was shown for C57 $\times$ C57 ectoplacental cone outgrowths incubated with anti-C57 serum. The outer layer of cells of a 4-day 'o' outgrowth 


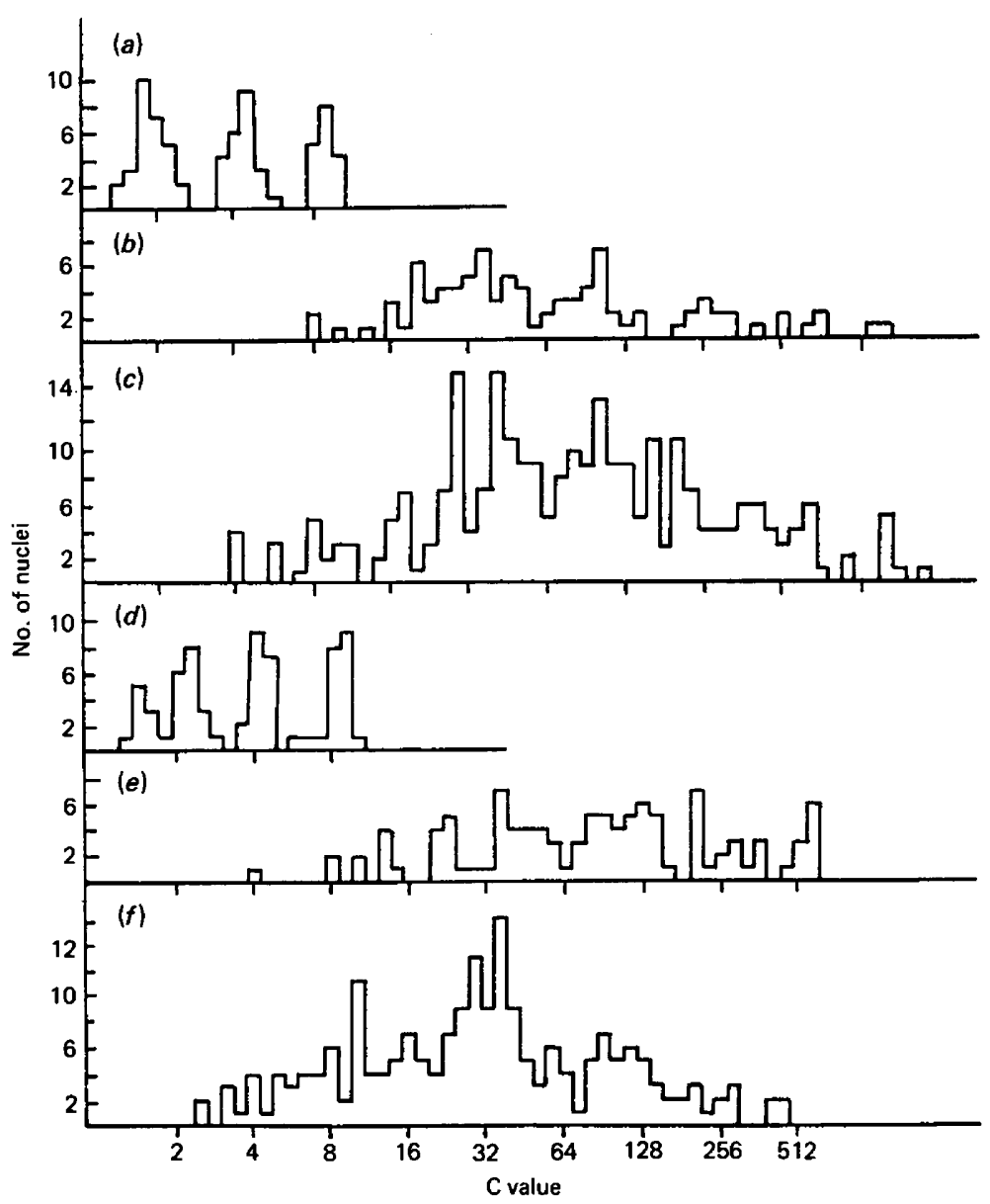

Text-fig. 1. Characteristic DNA frequency distributions for mouse ectoplacental cone trophoblast and liver cells after Feulgen staining and microdensitometry. (a) Liver nuclei from C57 mice; (b) the outermost layer of cells of four 'ao' C57 $\times$ C57 ectoplacental cone outgrowths; (c) the outermost layer of cells of four 'o' C57 $\times$ C57 ectoplacental cone outgrowths; (d) liver nuclei from CBA mice; (e) the outermost layer of 4 'ao' CBA $\times$ CBA ectoplacental cone outgrowths; (f) the outermost layer of 4 ' $\mathrm{o}$ ' CBA $\times$ CBA ectoplacental cone outgrowths.

\section{EXPLANATION OF PLATE 1}

Fig. 1. Two ectoplacental cone tips in culture. To the left an 'ao' after $24 \mathrm{~h}$ and to the right an ' $\mathrm{o}$ ' outgrowth after 3 days in culture. $H \& E, \times 125$.

Fig. 2. A 24-h 'ao' ectoplacental cone culture from a CBA $\times$ CBA mating incubated with anti-CBA serum in the mixed haemadsorption test. Note that there is no attachment of red cells. $H \& E, \times 125$.

Fig. 3. A 4-day 'o' ectoplacental cone culture from a CBA $\times$ CBA mating incubated with anti-CBA serum. Sensitized red blood cells have attached to the outer layers of cells. $H \& E$, $\times 50$.

Fig. 4. A 4-day 'o' ectoplacental cone outgrowth. Microdensitometry of all the outer layer of cells showed them to be polyploid. Feuglen staining, $\times 25$.

Fig. 5. A 2-day 'ao' ectoplacental cone outgrowth showing the 'broken away' polyploid cells. Feulgen staining, $\times 25$.

Fig. 6. A 2-day 'ao' ectoplacental cone outgrowth after mixed haemadsorption; sensitized RBCs have attached only to the 'broken away' cells. H \& E, $\times 25$. 

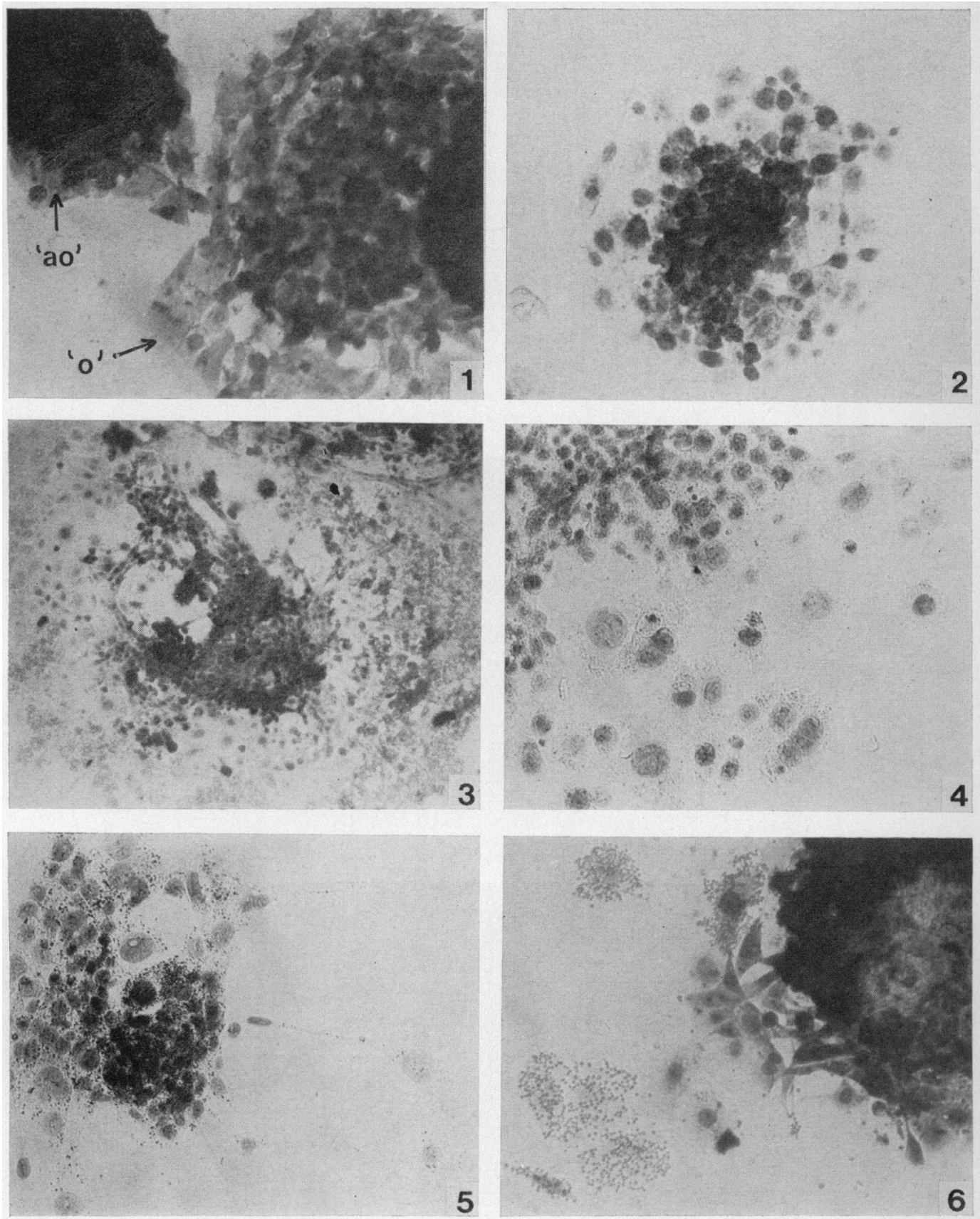

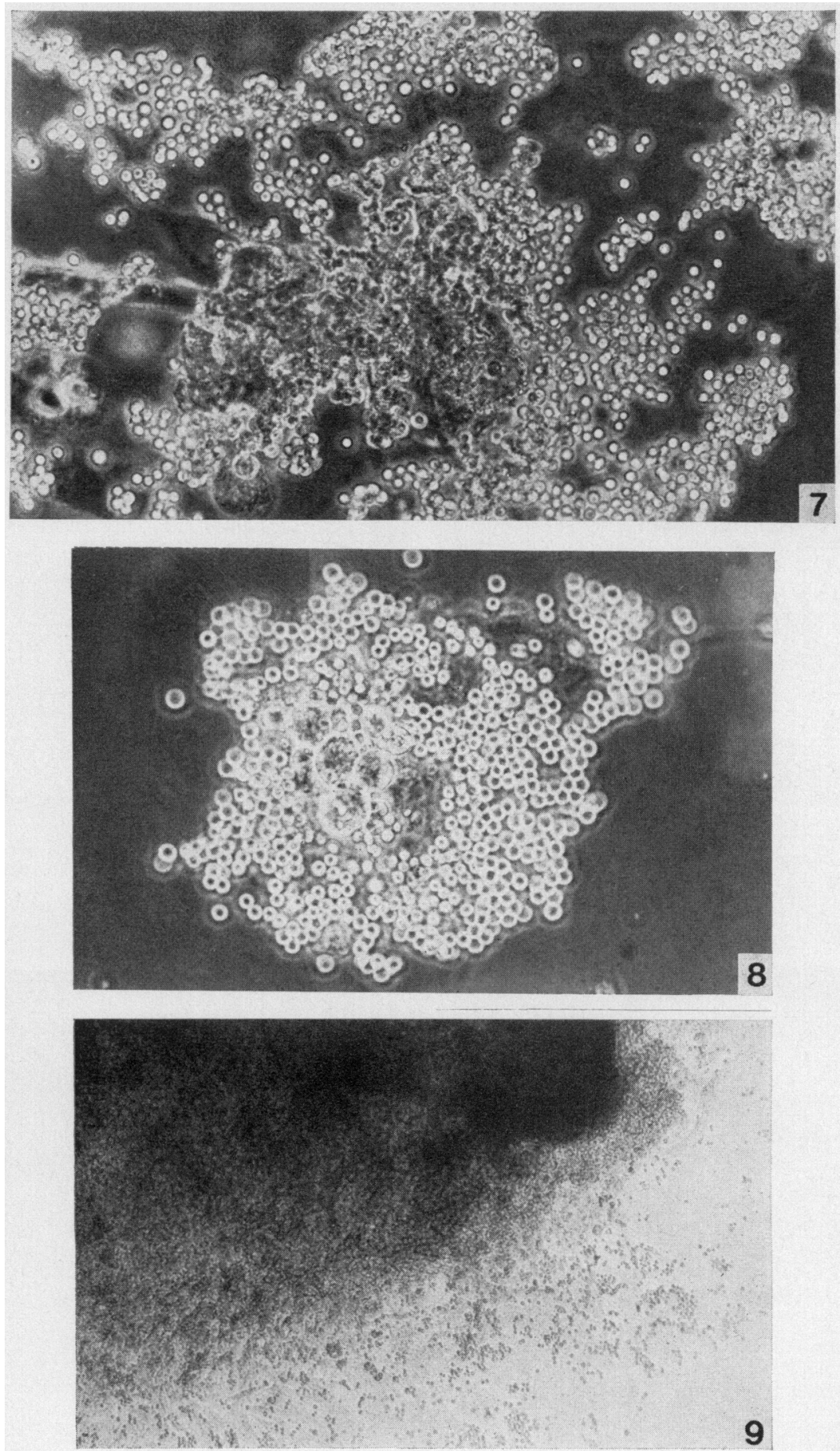
(Pl. 1, Fig. 3) was given a score of $4 \cdot 0$, although the first layers of secondary trophoblastic cells and the original ectoplacental cone were poorly labelled. Red cells became trapped in the cellular matrix of the initial tissue and after 4 days in culture there was some red cell attachment to the whole outgrowth. The embryonic cells retained the large size typical of trophoblast cells, and microdensitometry showed that all the cells of the outer layer in 'ao' and 'o' outgrowths were polyploid (see Text-fig. 1). The average amount of nuclear DNA for CBA 'ao' and 'o' and C57 'ao' cells was between 128 and 256 times the haploid amount of DNA measured in control cells of liver from the two strains and between 64 and 128 times for $\mathrm{C} 57$ ' $\mathrm{o}$ ' cells. The average number of cells in the outermost layer of the 'ao' and 'o' outgrowths measured was $25.0 \pm 1.9(n=8)$ and $58.9 \pm 4.7(n=8)$ respectively. Pl. 1, Fig. 4 shows an ' 0 ' outgrowth after Feulgen staining. After 1-2 days in culture the 'ao' outgrowths sometimes produced cells which grew rapidly away from the main mass of tissue but were still connected by cytoplasmic bridges (P]. 1, Fig. 5). The two large cells to the right of PI. 1, Fig. 5 had 256 and 64 times the haploid amount of DNA. Although the 'ao' outgrowth did not express antigens, the sensitized RBCs did attach to these 'broken-away' cells (see Pl. 1, Fig. 6).

\section{Blastocyst and placental trophoblast}

The mixed haemadsorption test for maternal and paternal antigens on cultures of blastocyst outgrowths was positive at both the 'ao' and ' $O$ ' stages of culture. Red cells attached to all cells of the culture, i.e. inner cell mass and trophoblast cells (PI. 2, Figs 7 and 8). Control 'ao' or 'o' outgrowths of CBA $\times$ CBA matings after incubation with anti-C57 serum showed no attachment of red cells. The same results were obtained with all outgrowths of C57 $\times$ CBA and C57 $\times$ C57 matings after incubation with appropriate antisera.

Red cell attachment occurred over the whole surface of 1- and 4-day placental cultures (Table 2: Pl. 2, Fig. 9).

Table 2. Expression of CBA and C57 cell surface antigens on blastocyst and placental cultures after mixed haemadsorption (mean score \pm s.e.m., no. of outgrowths in parentheses)

\begin{tabular}{|c|c|c|c|c|c|}
\hline \multirow[b]{2}{*}{ Parent mating } & \multirow[b]{2}{*}{ Antiserum } & \multicolumn{2}{|c|}{ Blastocyst } & \multicolumn{2}{|c|}{ Placenta } \\
\hline & & 'ao' outgrowth & 'o' outgrowth & 1-day culture & 4-day culture \\
\hline \multirow[t]{2}{*}{$\mathrm{CBA} \times \mathrm{CBA}$} & Anti-CBA & $3.86 \pm 0.09(7)$ & $3.80 \pm 0.06(34)$ & $3.67 \pm 0.06(5)$ & 4.00 \\
\hline & Anti-C57 & NE & $0(20)$ & $0(3)$ & $\mathrm{NE}$ \\
\hline \multirow[t]{2}{*}{$\mathrm{C} 57 \times \mathrm{CBA}$} & Anti-CBA & $3.25 \pm 0.14$ & $2.89 \pm 0.16(9)$ & $3.68 \pm 0.05$ & $3.67 \pm 0.05$ \\
\hline & Anti-C57 & $\mathrm{NE}$ & $3.00(6)$ & $3 \cdot 29 \pm 0.13(4)$ & $3.24 \pm 0.08(6)$ \\
\hline \multirow[t]{2}{*}{$\mathrm{C} 57 \times \mathrm{C} 57$} & Anti-CBA & $\mathrm{NE}$ & $0(10)$ & $0(3)$ & NE \\
\hline & Anti-C57 & $3.06 \pm 0.15(8)$ & $3.86 \pm 0.14(4)$ & $3.08 \pm 0.12(6)$ & $\mathrm{NE}$ \\
\hline
\end{tabular}

$\mathrm{NE}=$ not examined.

\section{EXPLANATION OF PLATE 2}

Fig. 7. A 4-day 'o' blastocyst outgrowth from a C57 $\times$ CBA mating after incubation with anti-CBA serum The outgrowth was given a score of 3.0 in the mixed haemadsorption test. Phase contrast, $\times 355$.

Fig. 8. A 2-day 'ao' blastocyst outgrowth from a CBA $\times$ CBA mating after incubation with anti-CBA serum. The RBCs on the inner cell mass are in another focal plane. Phase contrast, $\times 300$.

Fig. 9. A 1-day placental outgrowth from a $\mathrm{C} 57 \times \mathrm{C} 57$ mating after incubation with anti-C57 serum. Note the RBC attachment throughout the culture. H \& E, $\times 60$. 


\section{Hormone incubation}

When CBA $\times$ CBA blastocysts and ectoplacental cones were incubated with medium containing 10 or $2.5 \mu \mathrm{g}$ progesterone $/ \mathrm{ml}, 100 \mu \mathrm{g}$ or $25 \mathrm{ng}$ oestradiol $-17 \beta / \mathrm{ml}$ or $10 \mu \mathrm{g}$ progesterone $+25 \mathrm{ng}$ oestradiol- $17 \beta / \mathrm{ml}$ there was no difference in the amount of red cell attachment or to the area to which the cells attached. All groups gave average scores exceeding 3.0 when incubated with anti-CBA serum and negative scores when incubated with anti-C57 serum. Incubation with $0.1,1.0$ or 10.0 i.u. hCG/ml culture medium also had no effect.

\section{Discussion}

Primary trophoblastic giant cells express maternal and paternal antigens (Carter, 1976b), and the present results show that these antigens are expressed at all stages of outgrowth of the blastocyst. However, in the mixed haemadsorption assay, there was no attachment of sensitized sheep RBCs to the surface of secondary trophoblast cells after incubation with antiserum to paternal or maternal strains. After 3-5 days in culture, the ectoplacental cone tissue has produced several layers of secondary giant cells, the outermost of which express antigens. When secondary giant cells of the ectoplacental cone are first put into culture, antigens are presumably either absent (Simmons, Cruse \& McKay, 1967) or masked, perhaps by a mucopolysaccharide (Kirby et al., 1964). The antigenic sites expressed when secondary giant cells are cultured for 3-5 days are strain-specific for C57 or CBA and of maternal and paternal origin. They could include either major (H-2) or minor (H-3 or H-6) histocompatibility antigens. Billington et al. (1977) used the mixed haemadsorption technique to show that H-2 and non-H-2 antigens were expressed on the cell surface of outgrowths for 7-day A-strain ectoplacental cones cultured for 5 days and these observations agree with the data presented here for cultures of that age.

The expression of cell surface antigens is dependent on growth conditions. Cikes \& Klein (1972) showed that the antigens on cultured mouse lymphoma cells were subject to considerable physiological variation: there was a decrease in antigen expression during rapid cell growth and in old cultures and expression was dependent on cell cycle stage with maximum expression during $\mathrm{G} 1$. The secondary giant cells which express antigens in the present experiments are the older cells in culture and show increased antigen expression. Although there was no measurable antigen on these cells during the first $24-48 \mathrm{~h}$ in culture, there was positive expression of primary giant cells and placental trophoblast at this time. It is unlikely, therefore, that the differential expression of antigens shown here has the same basis as the observations of Cikes \& Klein (1972).

The ectoplacental cone trophoblast used in the present experiments was taken 7 days after detection of a vaginal plug. Bernard, Ripoche \& Bennett (1977), using the same invasive giant cells of A-strain mice and immunoperoxidase labelling, observed that they were the only cells during embryo development to lack immunoglobulins. The cells of the 5-day embryo and the 10-day trophoblast are surrounded by immunoglobulins. Therefore the failure of Bernardet al. (1977) to detect immunoglobulins and the data presented here suggest a cell surface change in ectoplacental cone cells which prevents the attachment of immunoglobulin molecules.

Ferguson \& Palm (1977) were not able to demonstrate antigens on the trophoblast giant cells of the 12-13-day rat placenta, but antigens were detectable on cytotrophoblast and fibroblasts. In the present study of the mouse placenta it was not possible to isolate trophoblast giant cells from other cell types to determine whether they are labelled in the mixed haemadsorption test.

Progesterone, oestradiol and hCG have been shown to be immunosuppressive in some systems (Monroe, 1971; Wattman, Burde \& Berias, 1971; Contractor \& Davies, 1973; Martin, Spicer \& Smythe, 1974; Carter, 1976a). In this study, progesterone and oestradiol were used at concentrations known to have an effect on cell division of uterine tissue in vitro (Grant, 1973; Carter \& McLaren, 1975), but there was no change in the amount of labelling or area to which the sensitized RBCs attached to cells of ectoplacental cones or primary giant cells.

The present investigation shows that, in the mouse, antigenic expression on the secondary trophoblast cells of the ectoplacental cone differs from that n $_{\text {the }}$ thimary trophoblast of the blasto- $27 \mathrm{AM}$ 
cyst and the trophoblast of the placenta, suggesting that different mechanisms are involved in the protection of the fetus at the various stages of trophoblast development.

I thank Dr A. McLaren for her helpful criticism and advice and Mr J. McPartlin for help with the microdensitometry. I am grateful to the Irish Medical Research Council for financial support.

\section{References}

ANSEL, J.D. \& SNOW, M.H.L. (1975) The development of trophoblast in vitro from blastocysts containing varying amounts of inner cell mass. J. Embryol. exp. Morph.33, 177-185.

Bernard, O., Ripoche, M.A. \& BennetT, D. (1977) Distribution of maternal immunoglobulins in the mouse uterus and embryo in the days after implantation. J.exp. Med.145, 58-75.

Billington, W.D., Jenkinson, E.J., Searle, R.F. \& SelleNS, M.H. (1977) Alloantigen expression during early embryogenesis and placental ontogeny in the mouse: immunoperoxidase and mixed hemadsorption studies. Transplantation Proc. 9, 1371-1377.

CARTER, J. (1976a) The effect of progesterone, oestradiol and $\mathrm{HCG}$ on cell-mediated immunity in pregnant mice. J. Reprod. Fert. 46, 211-216.

Carter, J. (1976b) Expression of maternal and paternal antigens on trophoblast. Nature, Lond. 262, 292-293.

Carter, J. \& McLaren, A. (1975) The effect of oestrogen and progesterone on the incorporation of tritiated thymidine in mouse uteri in vitro. $J$. Reprod. Fert. 42, 439-445.

Cikes, M. \& KleIN, G. (1972) Quantitative studies of antigen expression in cultured murine lymphoma cells. I. Cell surface antigens in "asynchronous" cultures. J. natn. Cancer Inst. 49, 1599-1606.

Contractor, S.F. \& Davies, H. (1973) Effect of human chorionic somatomammotrophin and human chorionic gonadotrophin on phytohaemagglutinininduced lymphocyte transformation. Nature, New Biol. 243, 284-286.

Currie, G.A. \& Bagshawe, K.D. (1967) The masking of antigens on trophoblast and cancer cells. Lancet $\mathbf{i}$. 708-710.

Currie, G.A., Van Doorninck, W. \& Bagshawe, K.D. (1968) Effect of neuraminidase on the immunogenicity of early mouse trophoblast. Nature, Lond. 219, 191-192.

EDWARDS, R.G. \& CoomBs, R.R.A. (1974) Immunological interactions between mother and fetus. In Clinical Aspects of Immunology, pp. 561-597. Eds P. G. H. Grell, R. R. A. Coombs \& P. J. Lachmann. Blackwell, Oxford.

Fagraeú, A., Espmark, J.A. \& Jonsson, J. (1965) Mixed haemadsorption: a mixed antiglobulin reaction applied to antigens on a glass surface. Immunology 9, 161-175.

Ferguson, F.G. \& Palm, J. (1977) Reactivity of rat placental cells with alloantisera. J. Embryol. exp. Morph.39, 195-202.

GATES, A.H. (1971) Maximising yield and developmental uniformity of eggs. In Methods in Mammalian
Embryology, pp. 64-75. Ed. J. C. Daniel, Jr. Freeman Press, San Francisco.

GRANT, P. (1973) The effect of progesterone and oestradiol on immature mouse uteri maintained as organ cultures.J. Endocr.57, 171-174.

HulkA, J.F. \& MoHR, K. (1968) Trophoblast antigenicity demonstrated by altered challenge of graft survival. Science, N. Y. 161, 696-698.

JoHnson, M.H. (1975) Antigens of peri-implantation trophoblast. In Immunobiology of the Trophoblast, pp. 87-100. Eds R. G. Edwards, C. W. S. Howe \& M. H. Johnson. Cambridge University Press.

Kirby, D.R.S., Billington, W.D., Bradbury, S. \& Goldstein, D. (1964) Antigen barrier of the mouse placenta. Nature, Lond. 204, 548-549.

Martin, B.J., SpICER, S.S. \& SMYthe, N.M. (1974) Cytochemical studies of the maternal surface of the syncytiotrophoblast of human early and term placenta. Anat. Rec. 178, 769-786.

MONROE, J.S. (1971) Progesteroids as immunosuppressive agents. J. Reticuloendothelial Soc. 9, 361365.

SCHLESINGER, J. (1964) Serologic studies of embryonic and trophoblastic tissues of the mouse. Immunology 93, 255-263.

SeARle, R.F., Jenkinson, E.J. \& Johnson, M.H. (1975) Immunogenicity of mouse trophoblast and embryonic sac. Nature, Lond. 255, 719-720.

Seliens, M.H. (1977) Antigen expression on early mouse trophoblast. Nature, Lond. 269, 60-61.

Simmons, R.L. \& RUSSELl, P.S. (1967) Xenogeneic antigens in mouse trophoblast. Transplantation $\mathbf{5}$, 85-88.

Simmons, R.L., Cruse, V. \& McKay, D.G. (1977) The immunologic problem of pregnancy. II. Ultrastructure of isogeneic and allogeneic trophoblastic transplants. Am. J. Obstet Gynec. 97, 218-230.

Simmons, R.L., Lipschultz, M.L., Rios, A. \& Ray, R.K. (1971) Failure of neuraminidase to unmask histocompatibility antigens. Nature, New Biol. 213, 111-112.

Tachibana, T., Worst, P. \& Klein, E. (1970) Detection of cell surface antigens on monolayer cultures. II. The application of M.H.A. on a microscale. Immuno$\log y 19,809-816$.

Uhr, J.W., \& ANDerson, S.G. (1962) The placenta as a homotransplant. Nature, Lond. 194, 1292-1293.

Wattman, S.R., BuRde, R.M. \& BerIas, J. (1971) Prevention of corneal homograft rejection by estrogens. Transplantation 11, 194-196.

Received 2 May 1978 